\title{
Water Supply Scheme in Morotai Island
}

\author{
Wulan Seizarwati ${ }^{*}$, Heni Rengganis, Muhshonati Syahidah, Waluyo Hatmoko, \\ Derry Prasetya \\ Research Center for Water Resources, Ministry of Public Works and Housing, INDONESIA \\ Jalan Ir. H. Juanda No. 193 Bandung \\ *Corresponding authors: wulan_seizarwati@yahoo.com
}

SUBMITTED 15 November 2019 REVISED 13 December 2019 ACCEPTED 13 December 2019

\begin{abstract}
Morotai Island is designated as one of the National Tourism Strategic Area, and has increased demand for pure water. It is known as a dry area where water is difficult to obtain, and therefore, it is necessary to prepare a supply scheme to meet the island's demand. Hence, this study aims to obtain supply protocol from various available sources, in order to meet all water demands, especially for tourism sector development. The several methods used in this research include demand calculation for domestic, industry, irrigation, livestock, and tourism; rainfall-runoff simulation using Wflow model and estimation of groundwater availability using the baseflow recession method. Furthermore, surface balance shows the water availability in each sub-districts is not able to meet the demands. To overcome this problem, a supply scheme has been prepared, e.g. surface water utilization by constructing free intake in North Morotai, groundwater use by constructing dug and drilled wells in many locations, especially coastal areas, spring water utilization by creating a collection system (broncaptering) in Jaya, East and South Morotai. Furthermore, small islands can utilize springs and shallow dug wells, to prevent seawater intrusion from affecting the quality. The scheme suggests an appropriate infrastructural support to supply local communities, as well as develop the Island to be the new primary tourism center in Indonesia.
\end{abstract}

KEYWORDS Morotai; Supply Scheme; Tourism; Water Resources Infrastructure; Water Supply;

(c) The Author(s) 2020. This article is distributed under a Creative Commons Attribution-ShareAlike 4.0 International license.

\section{INTRODUCTION}

Indonesia is an archipelagic country consisting of small and big islands with abundant natural resources. A good example with the potential of being developed is Morotai because of its natural beauty. It is located in the Northern part of Maluku Islands, known as the East Indonesia hidden paradise. Therefore, according to the Government Regulation No. 50 of 2011 on Master Plan of National Tourism Development for 2010 2025, Morotai was designated as one of the tourism strategic area (Republic of Indonesia, 2011), therefore the development of this region will be prioritized by the appropriate sector. Furthermore, the tourism sites on the island include an underwater tour, small areas of land, cave, World War II museum, waterfall, and others. The area development will increase water demands and also the infrastructure necessary for adequate supply. Also, this Island is known as a dry area so it is difficult to obtain water. Hence, it is necessary to prepare a supply scheme to meet the demands. According to Soenarto et al. (2010), clean water sources in small islands are very limited, due to their location which is isolated by the surrounding sea. Furthermore, the demands of a tourist center can be a problem, especially in regions of water scarcity, as occurs in most coastal areas and small islands. (Ecologic, 2007; Pigram, 2001; Gössling, 2001; Essex et al., 2004; Tortella \& Tirado, 2011; Gikas \& Tchobanoglous, 2009; Kent et al., 2002). Therefore, this study aims to obtain a pure water supply scheme from various available sources in Morotai, to meet the necessary demands, especially for tourism development. 
The island is located in North Maluku Province with a coordinate of $2^{0} 00^{\prime}-2^{0} 40^{\prime} \mathrm{N}$ and $128^{0} 15^{\prime}-$ $129^{\circ} 08^{\prime} \mathrm{E}$, with an area of $4301.53 \mathrm{~km}^{2}$ consisting of $2314.9 \mathrm{~km}^{2}$ land and $1970.93 \mathrm{~km}^{2}$ sea. Therefore, according to Soenarto et al. (2010), Morotai is a small island because its area is $\leqslant 5.000$ $\mathrm{km}^{2}$. Furthermore, it is surrounded by the Pacific Ocean on the Northern part, Halmahera Sea on the Western and Eastern part, and Strait on the Southern part (BPS, 2017).

In addition, the rainfall pattern is unique, and it can be categorized as a monsoon type which is influenced by local factors (Aldrian \& Susanto, 2003; Visa \& Harjana, 2015). Also, it can be seen in two rainy season peaks, which are DecemberJanuary-February and May-June. It is located in North Halmahera Basin, and the river flows in a dendritic pattern which indicates that the island generally has a sloppy topography. Therefore, it flows to the West and East with widths ranging from $4-80 \mathrm{~m}$. Furthermore, in terms of groundwater condition, Morotai has 1 basin called Daruba - Bere-bere with an area of $486 \mathrm{~km}^{2}$ or about $21 \%$ of the total. This basin lies in the coastal area especially in the East and South which is lithologically formed by gravel, sand, clay, and boulder. Therefore, it is categorized as aquifers with moderate and local productivity. This information is used as a consideration in determining a water supply scheme.

\section{METHODS}

The data used in this study includes statistical data for demand calculation, discharge measurement and water level data monitored by river gauging installation at several points, groundwater sources data from field surveys such as springs, dug and drilled wells, and other supporting data.

\subsection{Water Demand Calculation}

This is referred to SNI 6728.1-2015 concerning The preparation of Water Resources Balance which includes demand calculation of domestic, urban, industry, irrigation, and livestock. Tourism water demand follows the criteria set by Ditjen Cipta Karya (1996). Domestic demand is determined based on the city categories as presented in Table 1. Also, urban demand is assumed to be about $15 \%$ to $30 \%$ of domestic water needs. Therefore, the denser the population, the greater the water demand. Furthermore, industrial water needs can be calculated based on the number of employees, the area and type of industry.

The livestock needs can be determined based on the number and types, using the Equation (1).

$Q_{E}=\left(q_{(1)} x P_{(1)}+q_{(2)} x P_{(2)}+q_{(3)} x P_{(3)}\right)$

where $Q_{E}$ is water demand for livestock L/day, $q_{(1)}$ is for cow, buffalo, and horse, $q_{(2)}$ for goat and sheep, $q_{(3)}$ for poultry. Also, $P_{(1)}$ is the number of cows, buffalo, and horse, $P_{(2)}$ for goat and sheep, and $P_{(3)}$ is for poultry. Therefore, the water demand for each type of livestock is presented in Table 2.

Table 1. Domestic water demand based on categories of city

\begin{tabular}{llll}
\hline No & Categories of City & $\begin{array}{l}\text { Total Population } \\
\text { (persons) }\end{array}$ & $\begin{array}{l}\text { Water demand } \\
\text { (L/person/day) }\end{array}$ \\
\hline 1 & Capital of district/ village & $3000-20000$ & $60-90$ \\
2 & Small city & $20000-100000$ & $90-110$ \\
3 & Medium city & $100000-500000$ & $100-125$ \\
4 & Big city & $500000-1000000$ & $120-150$ \\
5 & Metropolitan & $>1000000$ & $150-200$ \\
\hline
\end{tabular}

(Source: BSN, 2015) 
Table 2. Water demand for livestock

\begin{tabular}{cll}
\hline No & Types of livestock & $\begin{array}{l}\text { Water demand } \\
\text { (Liter/person/day) }\end{array}$ \\
\hline 1 & Cow/ buffalo/horse & 40 \\
2 & Goat/ sheep & 5 \\
3 & Pug & 6 \\
4 & Poultry & 0.6 \\
\hline (Source: BSN, 2015) &
\end{tabular}

The calculation of irrigation water demand requires supporting data which consists of planting area, evapotranspiration, effective rainfall, soil type, and irrigation channel efficiency. Therefore, water needs for irrigation is calculated based on the location. The water demand per unit area is as shown in Equation (2).

$I G=\frac{\left(E_{t c}+I R+R W+P-E R\right)}{I E} \times A$

where $I G$ is the irrigation demand, $E_{t c}$ is consumptive needs, $I R$ is for land preparation, $R W$ is the demand to replace water layer, $P$ is percolation, $E R$ is effective rainfall, $I E$ is irrigation efficiency, and $A$ is the irrigation area. Therefore, the demand for hotels and tourism using the criteria based on Table 3 .

Table 3. Calculation criteria of hotels and tourism water demand

\begin{tabular}{llll}
\hline No & Description & Unit & Value \\
\hline 1 & Hotel & L/bed/day & 150 \\
2 & Tourism area & L/s/ha & $0.1-0.3$ \\
\hline
\end{tabular}

(Source: Ditjen Cipta Karya, 1996)

\subsection{Rainfall-Runoff Simulation}

In determining river discharge reliability at a certain location, it requires a long and continuous data. However, the information available on the Island is very limited. This is because there is only 1 discharge gauge, which is located in the South called Aha station, and has only 1-year data. Therefore, in this study, surface water availability is obtained from rainfall-runoff simulation using Wflow model, which is fully distributed, hydrological and can simulate the cycle process, starting from rainfall to finally getting the river flow. Furthermore, this model consists of $3 \mathrm{sub}$ modules which are interception calculated by Gash schematization, soil (TOPOG_SBM) including lateral groundwater flow and kinematic wave routing module. Also, as an input data, it requires a daily rainfall information from the Tropical Measuring Mission (TRMM) satellite and evapotranspiration data from Consultative Group on International Agricultural Research (CGIAR). In addition, it is supported by static data in topography form, land use, soil type, and more.

\subsection{Groundwater Recharge Estimation}

In this study, groundwater availability was estimated through recharge capacity calculation by applying the baseflow recession method. Baseflow is the water flow that reaches the groundwater level then flows in the aquifer until it fills out the river body (Fetter, 2001). Therefore, this method was applied as an approach to calculate the amount of recharge capacity, which is represented as baseflow that comes out to the river at the end of the rainy season. Also, the term recession refers to the decrease in discharge, naturally due to the absence of input recharge which follows an exponential pattern (Domenico \& Schwartz, 1990). In this calculation, it was assumed that the groundwater flows to the surface both directly and through spring, so that baseflow value can be determined as groundwater recharge. In addition, the calculation was performed on hydrograph at a single location as a time function, and the formula used is as described in Equation (3) and (4).

$K=\left(\frac{Q_{t}}{Q_{0}}\right)^{\frac{1}{t}}$

$k=-\ln K$

where $Q_{0}$ is initial discharge, $Q_{t}$ is value at $t, k$ is baseflow recession, and $t$ is time. This value can be used to estimate groundwater storage and recharge capacity using Equation (5) and (6).

$V_{t}=\frac{Q_{t}}{k}$ 
$R=\frac{V_{t}}{L}$

where $V_{t}$ is groundwater storage and $L$ is the catchment area. Therefore, the recharge value is obtained by dividing storage with the watershed area.

\section{RESULT AND DISCUSSION}

\subsection{Water Demand}

The results shows the total domestic water demand on the Island is $128.28 \mathrm{~L} / \mathrm{s}$. Furthermore, the biggest need is in the southern, which is $47 \mathrm{~L} / \mathrm{s}$ because of the urban center located in that region named Daruba City. Also, the industrial need is only $0.67 \mathrm{~L} / \mathrm{s}$. However, based on the spatial plan (RTRW) of Morotai District 2012 - 2032, the large marine energy and copra industry will be developed in Morotai Jaya, which will require a predicted need of about $781 \mathrm{~L} / \mathrm{s}$.

The demands for irrigation are calculated in 6 areas, which are Aha and Daeo in South; Tiley in South-West; Sambiki, Sangowo, and Wewemo in the East of the island with a total irrigation area of $632 \mathrm{Ha}$. Therefore, the average need in the South is $1042.6 \mathrm{~L} / \mathrm{s}$, South-West is $502.1 \mathrm{~L} / \mathrm{s}$ and East is $446.8 \mathrm{~L} / \mathrm{s}$. Also, livestock includes poultry, goat, cow, duck, pig, and buffalo with a population-of about $10-13 \%$. Hence, the highest livestock demand in the South is, $0.002 \mathrm{~L} / \mathrm{s}$, while it is about $0.001 \mathrm{~L} / \mathrm{s}$ in other subdistricts. Furthermore, the highest tourism need is in the South and is about $80.4 \mathrm{~L} / \mathrm{s}$, while in other regions namely South-West and North are 57.81 and 2.96 $\mathrm{L} / \mathrm{s}$. In addition, the supply for tourism is currently from rivers, springs, and dug wells. Therefore, the city's development is concentrated in the South, making the demand in this area the highest compared to other regions. The total water demand for each sub-district is presented in Table 4. The highest water demand is in South Morotai, i.e. $812.9 \mathrm{~L} / \mathrm{s}$ followed by Morotai Jaya 795 L/s, South-West $417.3 \mathrm{~L} / \mathrm{s}$, East $308.4 \mathrm{~L} / \mathrm{s}$, and North $28.2 \mathrm{~L} / \mathrm{s}$.

\subsection{Water Availability}

The analysis begins with water resources identification through field surveys. Based on geology, it is dominated by limestone and other types of rocks such as lava, breccia, sand, and silt. Therefore, information about the lithology can be used as an initial description relating to groundwater potential in this region. Also, the sources identified based on field surveys include river, spring, dug and drilled wells. However, it is believed that there are still other sources yet to be identified. Furthermore, the springs that emerge are generally due to rock breaks in limestone formation or underground rivers that emerge to the surface.

Besides Morotai, field surveys are also conducted on the small islands around. Therefore, from 33 located in the District, 14 has been visited (Table 5). Rao is the second-largest with an area less than $1 \mathrm{~km}^{2}$. Also, they are generally inhabited, although some of them are only occupied by the officials of local tourism service. Furthermore, some of the islands functioning as a tourism center includes Zumzum, Dodola Besar, Dodola Kecil, Galo - Galo Kecil, Kokoya, Dowongidare, and Matita. However, Rao only functioned as a residence, while others are not only for residential purposes but also for fishing and tourism. The result of the survey can be seen in Figure 1.

In terms of sources, almost all islands have dug wells to obtain groundwater to meet daily needs, including Rao, Saminyamau, Ngele-ngele Besar, Ngele-ngele Kecil, Zumzum, Kolorai, Dodola Besar, Galo-galo Besar, and Kokoya with water depth ranging from $1-4.5$ meter (Table 5). Also, in terms of quality, EC and TDS has not shown the effect of seawater intrusion. Therefore, further studies are needed regarding this condition. Other sources are also found in Rao like springs and rivers such as Galopu, Buras, Dolam, and Cebubu. Furthermore, Buras discharge, which is $26 \mathrm{~L} / \mathrm{s}$, has the most potential to be developed. 
Table 4 Total water demand in Morotai Island

\begin{tabular}{lllllllll}
\hline No & Sub-district & Domestic & Non-domestic & Industry & Irrigation & Livestock & Tourism & $\begin{array}{l}\text { Total water } \\
\text { demand (L/s) }\end{array}$ \\
\hline 1 & South & 37.6 & 11.3 & - & 681.8 & 1.8 & 80.4 & 812.9 \\
2 & East & 11.7 & 3.5 & - & 292.0 & 1.2 & - & 308.4 \\
3 & South-West & 15.9 & 4.8 & 9 & 328.0 & 1.0 & 57.8 & 417.3 \\
4 & North & 12.0 & 3.6 & 9 & - & 0.6 & 3.0 & 28.2 \\
5 & Morotai Jaya & 10.3 & 3.1 & 781 & - & 0.6 & - & 795.0 \\
\hline
\end{tabular}

Table 5. Raw water source identification in small islands surrounding Morotai.

\begin{tabular}{lllll}
\hline No & Name of island & Area $\left(\mathrm{km}^{2}\right)$ & Function & Water sources \\
\hline 1 & Tabailenge & 0.098 & Fishing and tourism & Not available \\
2 & Rao & 60.857 & Residence & River, spring, and dug wells \\
3 & Saminyamau & 0.385 & Residence and tourism & Dug wells and from spring in Rao \\
4 & Ngele-ngele Besar & 1.420 & Residence and tourism & Dug wells \\
5 & Ngele-ngele Kecil & 0.120 & Residence and tourism & Dug wells \\
6 & Zumzum & 0.726 & Tourism & Dug wells \\
7 & Kolorai & 0.186 & Residence and tourism & Dug wells \\
8 & Dodola Besar & 0.712 & Tourism & Dug wells \\
9 & Dodola Kecil & 0.071 & Tourism & Not available \\
10 & Galo-galo Besar & 0.316 & Residence and tourism & Dug wells \\
11 & Galo-galo Kecil & 0.123 & Tourism & Not available \\
12 & Kokoya & 0.115 & Tourism & Dug wells \\
13 & Dowongidare & 0.005 & Tourism & Not available \\
14 & Matita & 0.425 & Tourism & Not available \\
\hline
\end{tabular}

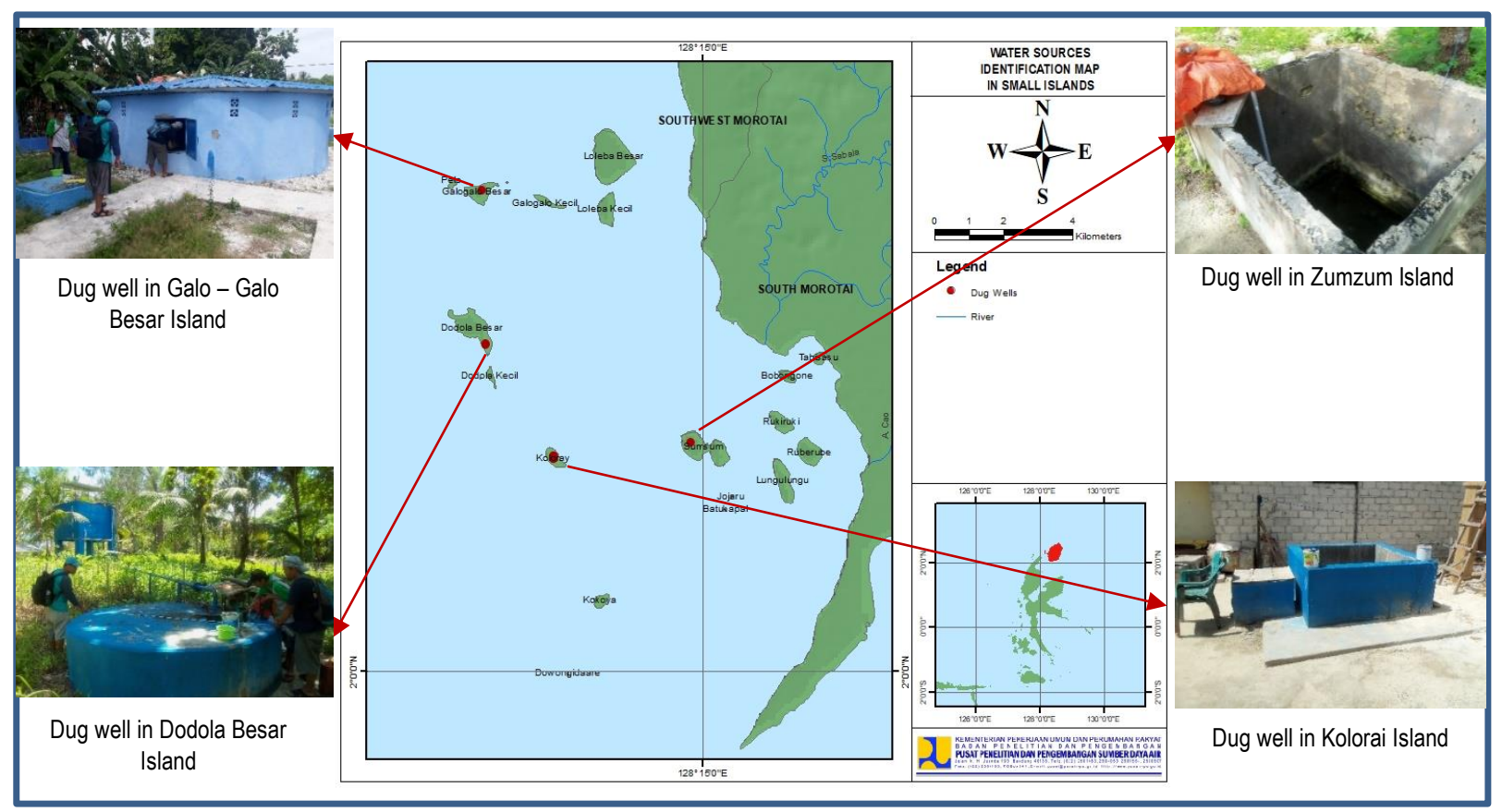

Figure 1. Water sources identification map in small islands 
The results of the field surveys and water source identification are not enough to describe a whole water availability potential. Therefore, the rainfall-runoff simulation was conducted to obtain a dependable flow from each subcatchment. Furthermore, the rainfall-runoff model used in this study is a distributed hydrological type by Wflow, where the calculation process was performed in each grid, and it is used to simplify the complex real-world in the model. Also, the Wflow for Morotai was built with a tool called Wflow-model builder with local and global data input. Since the area is quite small, more detailed visual representations are needed. Therefore, the Local maps used include river network, land use, and soil type with $100 \mathrm{~m}$ grid size. After it is successfully built, the next step is to prepare the dynamic input which includes rainfall data from TRMM satellite 16 years-long from 2002 to 2017 and evapotranspiration from CGIAR

The discharge generated was then processed to obtain the dependable flow in each catchment. Hence, the result shows the surface water sources on the island have the potential to be developed if there is an adequate infrastructure for the community to access water. In addition, this is supported by the rainfall pattern which has two rainy season peaks. The potential catchments are Cao, Sabatai Tua, Sakita, Tatamo, and Yao which $\mathrm{Q}_{90}$ is more than $5000 \mathrm{~L} / \mathrm{s}$.

In order to anticipate surface water shortage, this study also estimated the groundwater potential, which is represented by recharge capacity in each catchment by applying the baseflow recession method. Therefore the recharge capacity of each catchment is between $13.57-721 \mathrm{~mm} /$ year. Also, the percentage ranges from $1 \%-40 \%$ of rainfall. In addition, some catchments with a capacity of over $300 \mathrm{~mm}$ /year are Cio, Tutuhu, Sabatai Tua, Sangowo Kecil, Sangowo, and Lusuo.

\subsection{Water Balance}

Morotai consists of 5 subdistricts and each of them has a capital city where the regional development occurs (Figure 2). Therefore, the balance of water availability and water demand for each water district can be seen in Figure 2 to 7. Surface water balance shows that the water availability in each sub-district, cannot fulfill all water needs, and from the five sub-districts, only North have enough throughout the year. Furthermore, South Morotai experience shortage in April, East in April and November, South-West, and Jaya experience shortage for a whole year. Based on these results, it is necessary to utilize other sources to meet the demands on the Island.

\subsection{Water Supply Scheme}

In order to overcome the water shortage in several regions and also to prepare for tourism development on the Island, a supply scheme has been prepared as follows (Figure 8).

1. Morotai Jaya has a good potential for aquifer in the coastal area of the North and East part, for dug and drilled wells to be built. There is also a potential spring called Ake Tatum and 1 catchment which has enough recharge capacity called Aru, i.e. 339.6 mm/year.

2. North has potential surface water which can be developed by building free intake in Ngisio river, Kocago, Sakita, and Yao. This region also has 1 potential recharge capacity in Lusuo catchment, which is $432.6 \mathrm{~mm} /$ year.

3. On the coastal area of South-West, dug and drilled wells can be built since the aquifer has good potential to be utilized. Besides that, Tutuhu catchment area has enough recharge capacity of $338.8 \mathrm{~mm} /$ year.

4. East has a potential spring called Wawemo, an aquifer on the coastal part, and it also has enough recharge capacity in Sangowo and Sangowo Kecil catchments, which is 643.5 $\mathrm{mm} /$ year and $721.8 \mathrm{~mm} /$ year, respectively. 
5. South has a productive aquifer on the coastal part and there are springs that can be utilized called Kaca and Cobubu. In addition, there is 1 catchment that has enough recharge capacity which is Sabatai Tua with $697.5 \mathrm{~mm}$ /year.
Furthermore, small islands can utilize springs, and shallow dug wells to prevent the quality from being affected by seawater intrusion, rivers by building free intake, rainwater harvesting, and more.

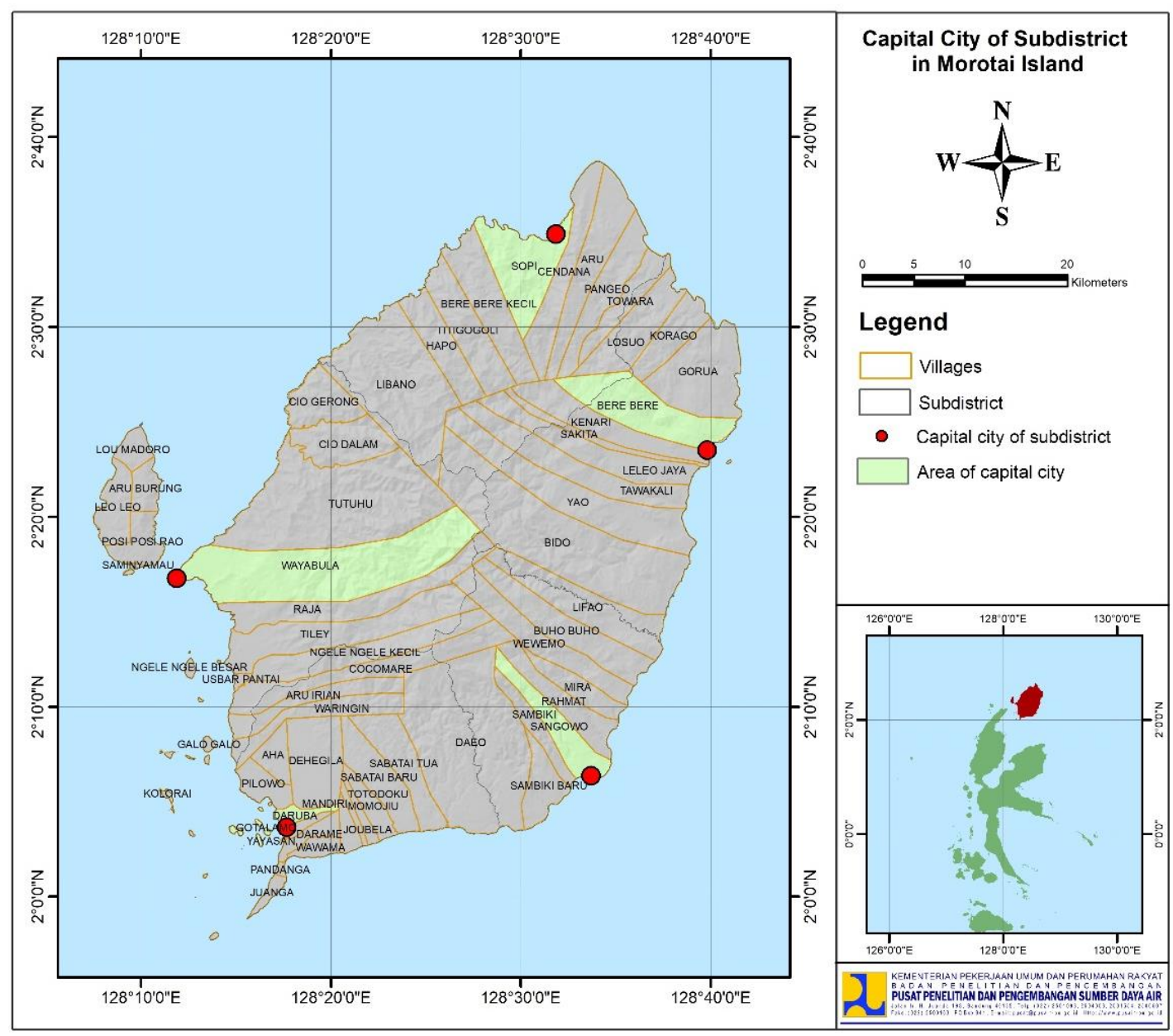

Figure 2. Capital city of subdistricts in Morotai Island

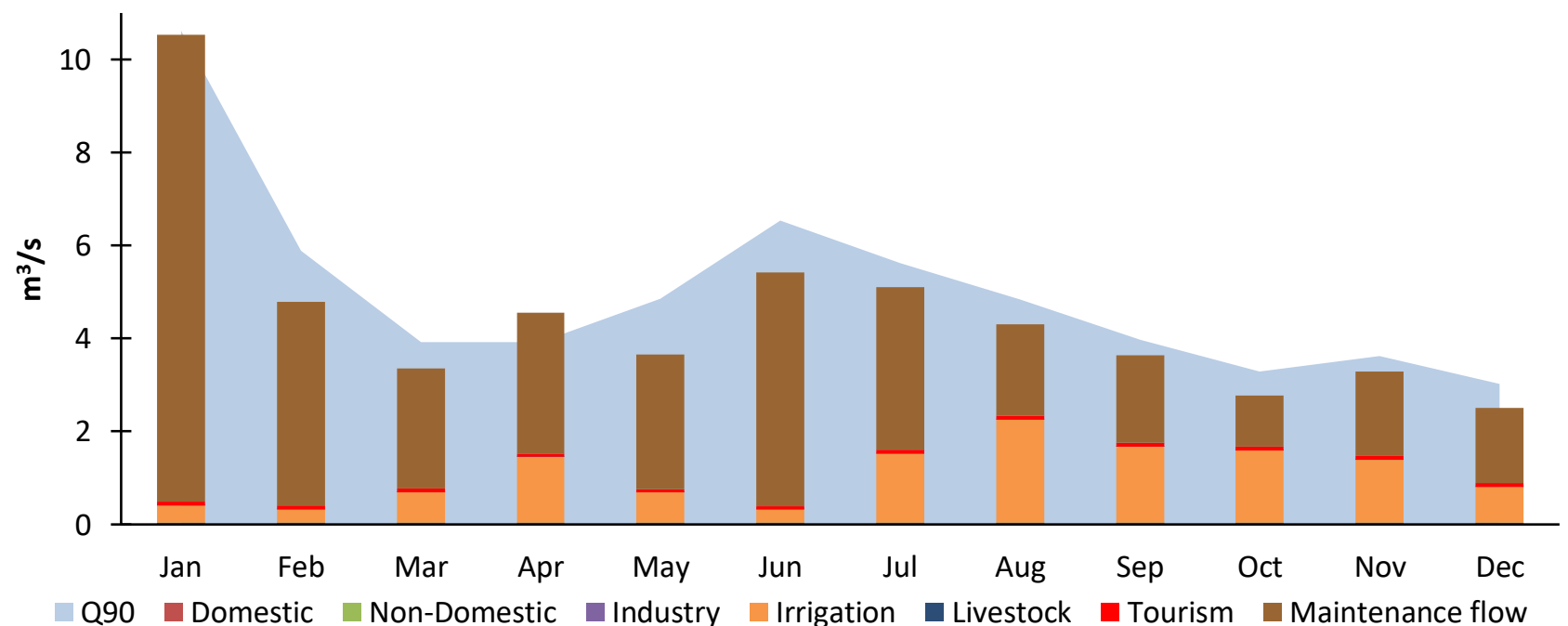

Figure 3. Water balance of South Morotai 


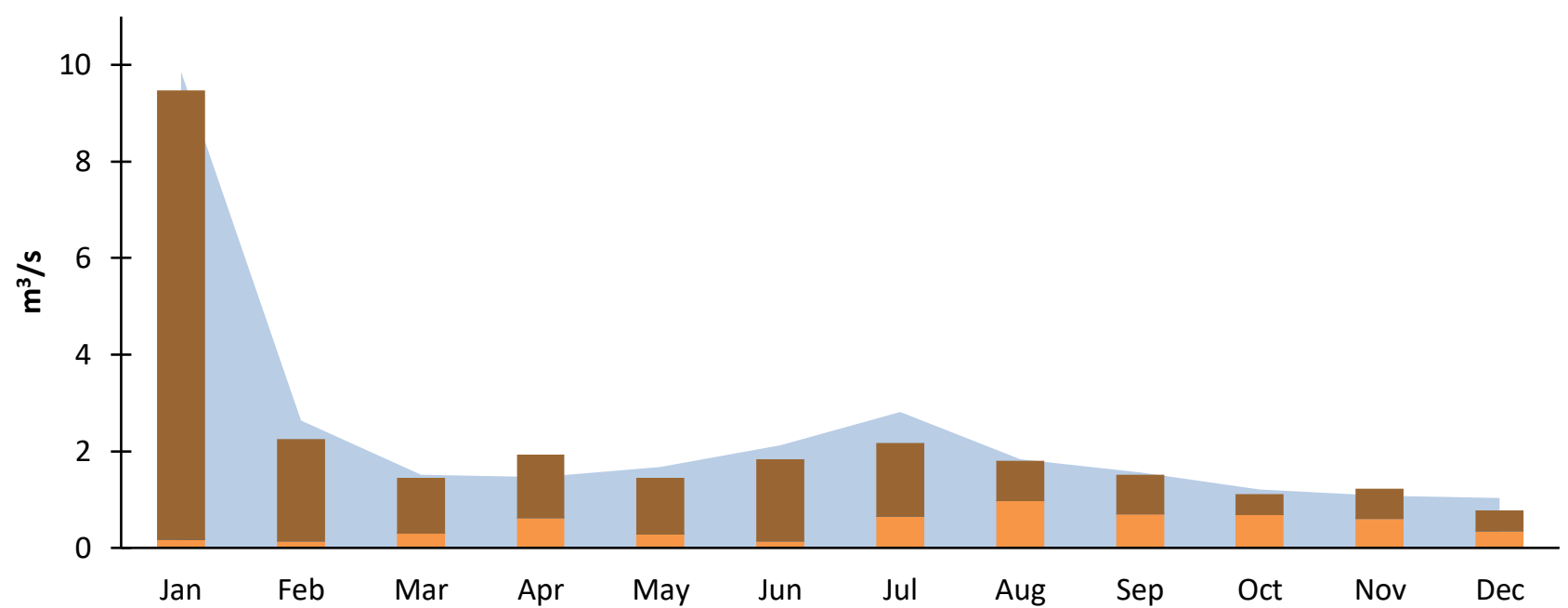

Q90 Domestic Non-Domestic a Industry Irrigation —Livestock - Tourism Maintenance flow

Figure 4. Water Balance of East Morotai

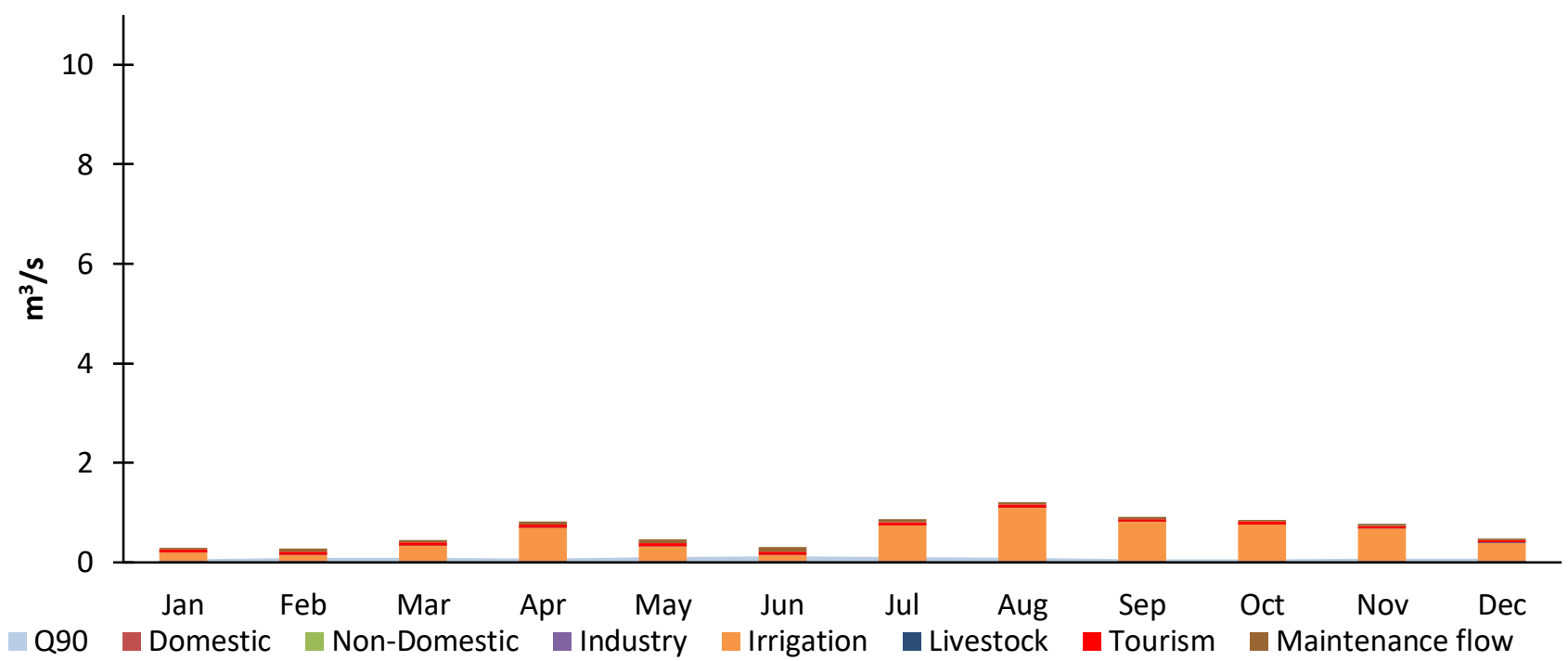

Figure 5. Water balance of South West Morotai

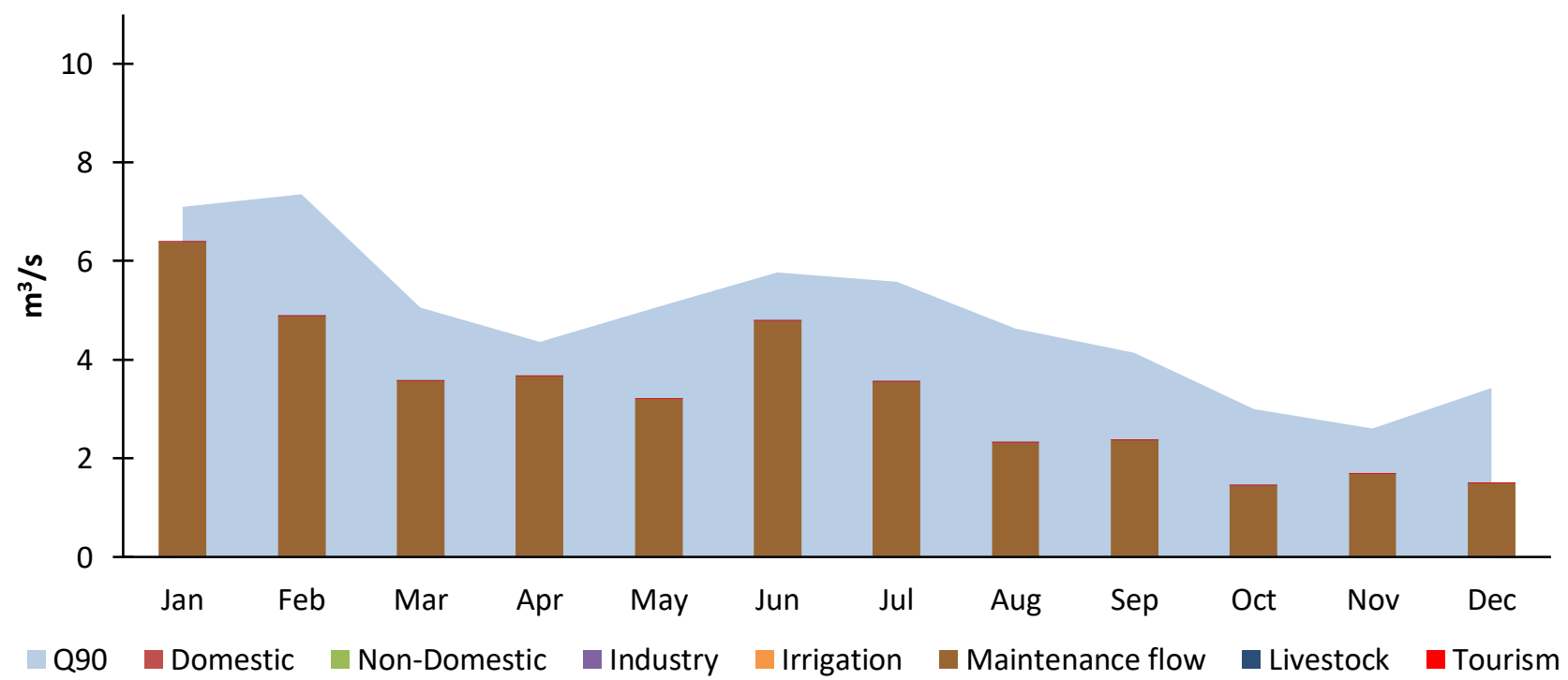

Figure 6. Water balance of North Morotai 


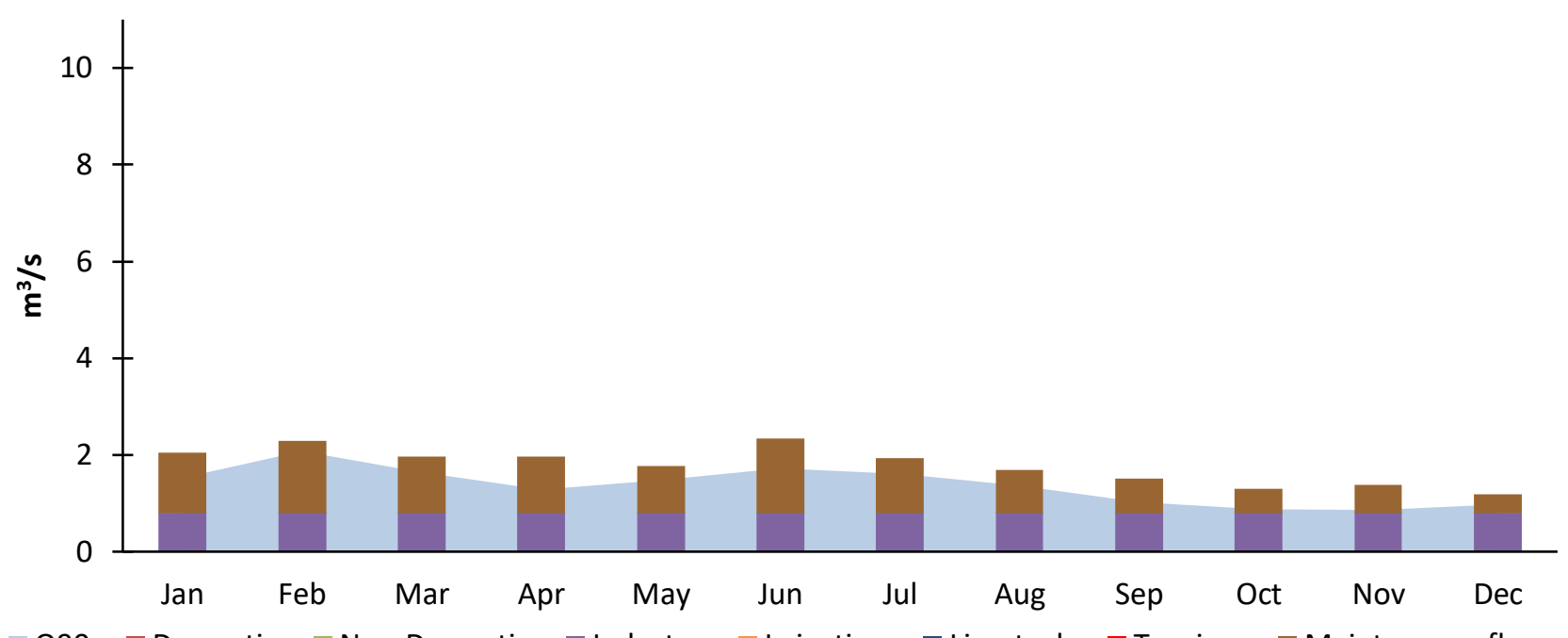

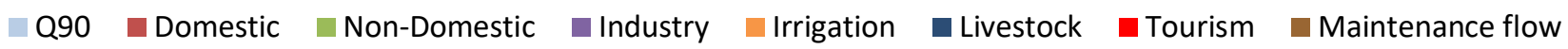

Figure 7. Water balance of Morotai Jaya

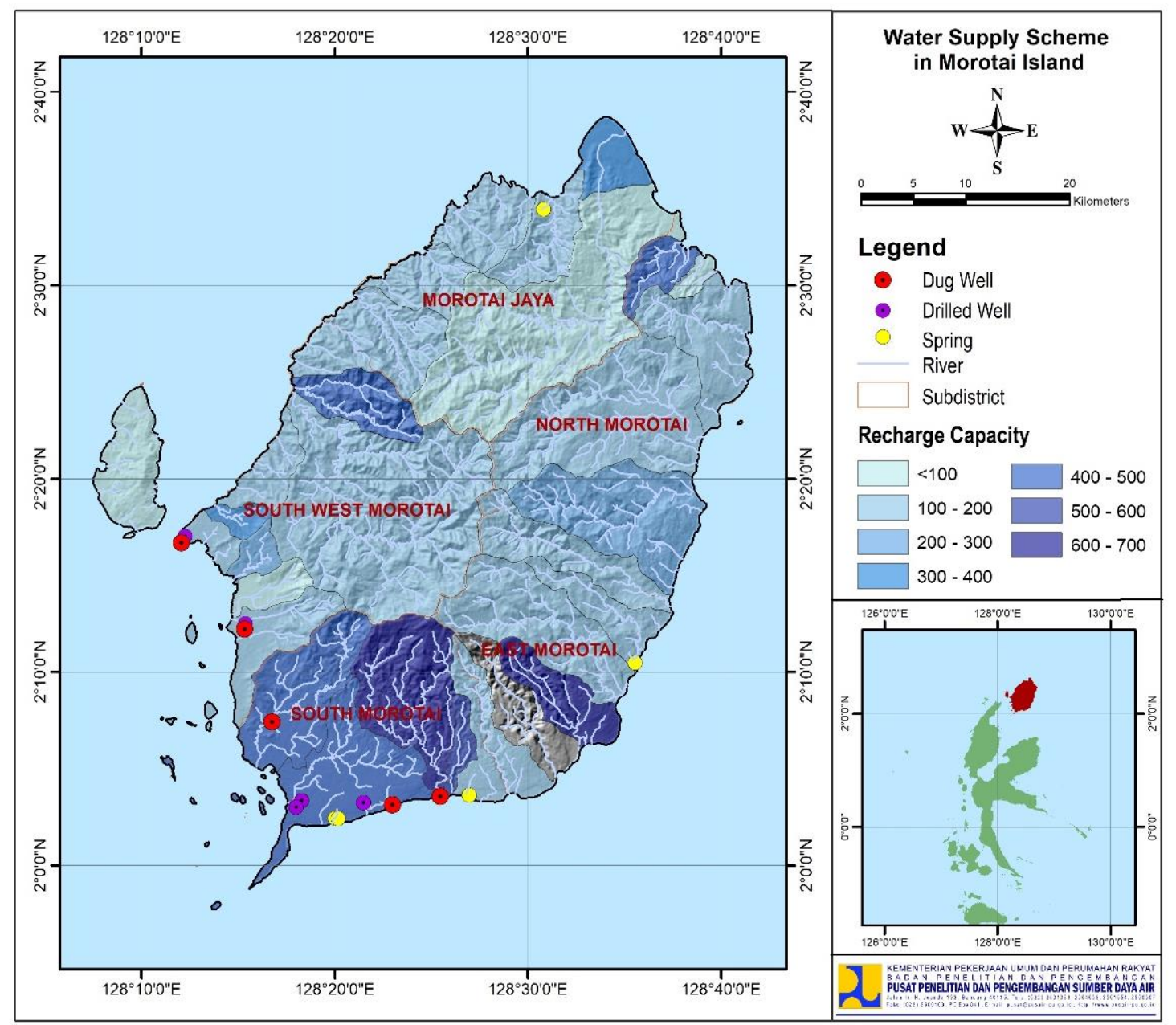

Figure 8. Water supply scheme in Morotai Island

\section{CONCLUSION}

This study concludes that Morotai Island can be developed in various sectors, especially tourism because it is supported by potential water resources, including river, spring, and groundwater. However, with the present limited infrastructure, there is a shortage in some areas, 
especially in the dry season. This is evident in the community's difficulty in accessing water, especially good quality of clean water. Therefore, to overcome this problem, supply scheme has been prepared, e.g. surface water utilization in the North by constructing free intake, groundwater use in most areas by constructing dug and drilled wells, spring water in Jaya, East, and South by constructing spring collection system. The water supply scheme suggests an appropriate infrastructure to support the water supply for local communities, as well as for Island development to become the new primary tourism center in Indonesia. This study can be used as preliminary information for further research, especially those relating to the selection of appropriate infrastructure in utilizing the available resources. In addition, it can also be used as a reference for similar research in water supply development on other small islands.

\section{DISCLAIMER}

The authors declare no conflict of interest.

\section{ACKNOWLEDGMENTS}

The authors are grateful for the opportunity given by the Research Center for Water Resources, Ministry of Public Works and Housing to carry out research relating to water availability in Morotai Island in 2018.

\section{REFERENCES}

Aldrian, E. dan R.Susanto, 2003. Identification of Three Dominant Rainfall Regions Within Indonesia and Their Relationship to Sea Surface Temperature. Int. J. Climatol, Vol. 23, N, 1435 1452.

Badan Pusat Statistik, 2017. Kabupaten Pulau Morotai Dalam Angka 2017. Badan Pusat Statistik Kabupaten Pulau Morotai.

Badan Standardisasi Nasional. (2015). SNI 6728.1-2015 tentang Penyusunan Neraca Sumber Daya Alam - Bagian 1: Sumber Daya Air.
Ditjen Cipta Karya, 1996. Kriteria Perencanaan Ditjen Cipta Karya. Dinas Pekerjaan Umum.

Domenico, P. \& Schwartz, F., 1990. Physical and Chemical Hydrogeology. USA: John Wiley \& Sons, Inc.

Ecologic, 2007. Final Report. EU Water Saving Potential (Part 1 - Report) ENV D.2/ETU/2007/0001r. Institute for International and European Environmental Policy.

Essex, S., Kent, M., and Newnham, R, 2004. Tourism Development in Mallorca: is Water Supply a Constraint? Journal of Sustainable Tourism 12(1), $4-28$.

Fetter, C., 2001. Applied Hydrogeology. USA: Prentice-Hall, Inc.

Gikas, P. \& Tchobanoglous, G., 2009. Sustainable Use of Water in the Aegean Islands. Journal of Environmental Management 90, 2601 - 2611.

Gössling, S., 2001. The Consequences of Tourism for Sustainable Water Use on a Tropical Island: Zanibar, Tanzania. Journal of Environmental Management 61, 179 - 191.

Kent, M., Newnham, R., and Essex, S., 2002. Tourism and Sustainable Water Supply in Mallorca: a Geographical Analysis. Applied Geography 22, $351-374$.

Pigram, J.J., 2001. Water Resources Management in Island Environments: the Challenge of Tourism Development. Tourism (Zagreb) 49 (3), 267 - 274.

Republik Indonesia, 2011. Peraturan Pemerintah Republik Indonesia Nomor 50 Tahun 2011 tentang Rencana Induk Pembangunan Kepariwisataan Nasional Tahun 2010 - 2025. Jakarta: Kementerian Sekretariat Negara RI.

Soenarto, B., Herawan, W., Rengganis, H., \& Mediawan, Y., 2010. Penyediaan Air Baku di Pulau - Pulau Kecil. Bandung: Pusat Penelitian dan Pengembangan Sumber Daya Air. 
Tortella, B.D. \& Torado, D., 2011. Hotel Water Consumption at a Seasonal Mass Tourist Destination. The Case of the Island of Mallorca. Journal of Environmental Management, Vol 92, $2568-2579$.
Visa, J. dan Harjana, T., 2015. Pola dan Distribusi Frekuensi Curah Hujan di Pulau Morotai Berbasis Data Satelit Tropical Rainfall Measuring Mission (TRMM). Jurnal Meteorologi dan Geofisika, 16 No. $1,11-17$ 
[This page is intentionally left blank] 